\title{
A Study on Nutrient Properties and Heavy Metal Concentrations of Waste Activated Sludge Derived from Municipal and Small Town Domestic Sewage Treatment Plants
}

\author{
Sun Xuekai \\ Institute of Applied Ecology \\ Chinese Academy of Sciences \\ Shenyang, China \\ e-mail: sunxuekai@iae.ac.cn
}

\author{
Huang Ye, Dong Xing, Xu Chengbin \\ College of Environmental Sciences \\ Liaoning University \\ Shenyang, China \\ e-mail: hhyy0125@126.com,1106048393@qq.com, \\ xuchengbin80@163.com
}

\author{
Bai Jie \\ Liaoning Provincial Society for Environmental Sciences \\ Department of Environmental Protection of Liaoning Province \\ Shenyang, China \\ e-mail: sbaijie@126.com
}

\begin{abstract}
In order to better understand land application of sewage sludge, the nutrient properties and heavy metal concentrations in sewage sludge were investigated from two different wastewater treatment plants in China. The results show that the OM contents were significantly different between Shenyang domestic sewage treatment plant and Ganqika domestic sewage treatment plant. The $O M$ contents were $48.75 \%$ and $77.66 \%$, respectively. The total nutrient contents, contained TN, TP and TK content, were $3.65 \%$ and $4.24 \%$, respectively. It was found that the total concentrations of As (182.7 $\mathrm{mg} / \mathrm{kg}$ dry matter) and $\mathrm{Ni}(\mathbf{1 0 9 . 0} \mathrm{mg} / \mathrm{kg}$ dry matter) in Shenyang sewage sludge, and $\mathrm{Hg}(23.7 \mathrm{mg} / \mathrm{kg}$ dry matter) in sewage sludge generated from Ganqika are higher than Chinese regulation limit of pollutant for sludge to be used for agriculture (GB18918-2002), $\mathrm{Hg}$ and $\mathrm{Ni}$ elements are main restrictive factor of sewage sludge application for agricultural use.
\end{abstract}

Keywords-domestic sewage sludge; nutrient; heavy metal; solid waste reuse

\section{INTRODUCTION}

The increasing generation of waste activated sludge by domestic sewage treatment plant brings significant pressure on the solid waste disposal. In China, production of waste activated sludge from is about $4000 \times 10^{4} \mathrm{t}$ in 2015. To minimize and utilize the excess activated sludge is becoming an important problem. At present, the use of excess activated sludge in agriculture and for land reclamation is increasingly being identified as the most potential disposal method for both soil conservation and residual resource utilization [1].

Waste activated sludge, a byproduct from the domestic wastewater treatment process, contains many valuable materials such as organic matter, nitrogen, phosphorus, and other nutrients. Therefore, sludge is a good soil conditioner for applying to soil improvement [2]. It can improve bulk density and aggregate stability, increase porosity and enrich soil by increasing organic matter and nutrients content [3, 4]. However, sludge addition has also produced undesirable changes, such as increases in heavy metal contents [5, 6]. Moreover, composition of sewage sludge strongly depends on the wastewater origin and on the treatment $[7,8]$. Thus, it is necessary to compare waste activated sludge characters derived from different kinds of domestic sewage treatment plant for avoiding environment and human health problems.

In this paper, we investigated the concentration levels of nutrient, as well as the heavy metals in sewage sludge from municipal and small town domestic sewage treatment plants. The aim of the present study was to monitor and assess sludge properties. The results can be very useful for the proper application of excess activated sludge from domestic sewage treatment plant into forest or agriculture soils.

\section{Materials AND Methords}

\section{A. Sample Collection}

Excess activated sludge samples were collected from two domestic sewage treatment plants, each one having a different size (here expressed in terms of $\mathrm{m}^{3} /$ day of wastewater entering the treatment plant on average): Shenyang (400,000 $\mathrm{m}^{3} /$ day) and Ganqika (50,000 $\mathrm{m}^{3} /$ day) The sludge samples were divided into two sub-samples. One sub-sample was air-dried at room temperature around $20^{\circ} \mathrm{C}$ was stored at $4{ }^{\circ} \mathrm{C}$ for later use. 


\section{B. Water Content, Organic Matter, Total Nitrogen, Total Phosphorus and Total Kalium}

Water content of fresh sludge samples was measured with gravimetric method. Air-dried soil samples were ground to pass through a $0.25-\mathrm{mm}$ sieve for the measurement of organic matter (OM), total nitrogen (TN), and total phosphorus (TP), and to pass through a $0.15-\mathrm{mm}$ nylon sieve for the measurement of total kalium (TK). The OM concentration was determined by the wet oxidation method with $\mathrm{K}_{2} \mathrm{Cr}_{2} \mathrm{O}_{7}$ and concentrated $\mathrm{H}_{2} \mathrm{SO}_{4}$. To determine TN and $\mathrm{TP}$, the samples were first digested using the Kjeldahl method [9]. The TN and TP concentrations in the digested solution were measured using a continuous-flow autoanalyzer (AutoAnalyzer III, Bran+Luebbe GmbH, Germany). TK was determined using ICP-Emission Spectrometry (PE OPTIMA 3000).

\section{Determination of the Total Concentration of Heavy Metal}

10 grams of air-dried samples, ground to pass through a 0.15-mm nylon sieve, were subjected to the total extraction procedure. According to the Chinese Standards CT/T2212005, the total concentration of heavy metals in sludge samples was determined by different method and experimental equipment. $\mathrm{Cu}, \mathrm{Pb}, \mathrm{Zn}$ and $\mathrm{Ni}$ were determined using Atomic Absorb Spectrometer (PE Analyst 100). Cd and $\mathrm{Cr}$ were analyzed using ICP-Emission Spectrometry (PE OPTIMA 3000). $\mathrm{Hg}$ and As were tested using Atomic Fluorescence Spectrometer (AFS-2202). Values were expressed as mg metal/kilogram of dry sludge.

\section{Statistical Analysis}

All trials were performed in triplicate to minimize experimental errors. The average of three replicates and standard deviation for sludge samples were calculated by Microsoft Office Excel 2010. Data were statistically analyzed using SPSS 13.0 for Windows software package.

\section{Resulets AND Discussion}

\section{A. Water Content and Nutrient Properties of Waste Activated Sludge}

The results of the water content, OM, TN, TP and TK analysis of waste activated sludge are shown in Table I.
TABLE I. WATER CONTENT AND NUTRIENT PROPERTIES ANALYSIS AT TWO DIFFERENT PLANTS

\begin{tabular}{|c|c|c|}
\hline \multirow{2}{*}{ Properties } & \multicolumn{2}{|c|}{ Domestic Sewage Treatment Plants } \\
\hline & Shenyang & Ganqika \\
\hline Water content(\%) & $82.64 \pm 0.09$ & $86.75 \pm 0.03$ \\
\hline $\begin{array}{l}\text { OM (on dry matter } \\
\text { basis) (\%) }\end{array}$ & $48.75 \pm 2.45$ & $77.66 \pm 4.69$ \\
\hline $\begin{array}{l}\text { TN (on dry matter } \\
\text { basis) (\%) }\end{array}$ & $1.97 \pm 0.15$ & $2.61 \pm 0.48$ \\
\hline $\begin{array}{l}\text { TP (on dry matter } \\
\text { basis) (\%) }\end{array}$ & $0.82 \pm 0.05$ & $1.03 \pm 0.14$ \\
\hline $\begin{array}{l}\text { TK (on dry matter } \\
\text { basis) (\%) }\end{array}$ & $0.86 \pm 0.06$ & $0.60 \pm 0.04$ \\
\hline
\end{tabular}

Sludge samples, collected after the mechanical drying process of municipal (Shenyang) and small town (Ganqika) domestic sewage treatment plants, have water contents more than $80 \%$.

The OM contents in sludge were significantly different between Shenyang domestic sewage treatment plant and Ganqika domestic sewage treatment plant. The OM contents were $48.75 \%$ and $77.66 \%$, respectively. The total nutrient contents, contained TN, TP and TK content, were $3.65 \%$ and $4.24 \%$, respectively. The results revealed that the contents of $\mathrm{OM}, \mathrm{N}, \mathrm{P}$ and $\mathrm{K}$ in sewage sludge are rich. Therefore, the sludge is a good soil conditioner for enriching soil.

\section{B. Heavy Metal in Sewage Sludge}

The concentrations of heavy metals expressed on a dry mass basis in sludge are given in Table II. Chinese standard (GB18918-2002) prohibits the use of sewage sludge as fertilizer in agriculture that exceeds the maximum values allowed for total concentrations of heavy metals (Table II). The data demonstrated that the total concentrations of As in Shenyang sewage sludge obviously exceed the limit values for basic soil according to the law. The total concentrations of $\mathrm{Hg}$ in Shenyang sewage sludge exceed the limit values for acidic soil and in Ganqika sewage sludge exceed the limit values for basic soil, while the total concentrations of $\mathrm{Ni}$ in Shenyang sewage sludge exceed the limit values for acidic soil according to the law. Therefore, As, Hg and Ni elements are main restrictive factor of sewage sludge application for agricultural use. 
TABLE II. The CONCENTRATION OF HEAVY METALS IN SEWAGE SLUDGE SAMPLING FROM DIFFERENT PLANTS AND THEIR COMPARISONS WITH MAXIMUM PERMITTED CONTENT USED FOR SOIL (GB18918-2002)

\begin{tabular}{|c|c|c|c|c|}
\hline \multirow{2}{*}{$\begin{array}{c}\text { Heavy Metals } \\
\text { (mg/kg dry } \\
\text { matter) }\end{array}$} & \multicolumn{2}{|c|}{$\begin{array}{c}\text { Domestic Sewage } \\
\text { Treatment Plants }\end{array}$} & $\begin{array}{c}\text { Maximum Permitted } \\
\text { Content Used for Soil } \\
\text { pH in China }\end{array}$ \\
\cline { 2 - 5 } & Shenyang & Ganqika & pH<6.5 & pH $\geq 6.5$ \\
\hline $\mathrm{Cd}$ & $3.4 \pm 0.6$ & $0.54 \pm 0.08$ & 5 & 20 \\
\hline $\mathrm{Hg}$ & $9.3 \pm 1.8$ & $23.7 \pm 3.2$ & 5 & 15 \\
\hline $\mathrm{As}$ & $182.7 \pm 41.5$ & $63.4 \pm 10.7$ & 75 & 75 \\
\hline $\mathrm{Cu}$ & $369.0 \pm 89.8$ & $65.7 \pm 13.2$ & 800 & 1500 \\
\hline $\mathrm{Pb}$ & $88.8 \pm 7.6$ & $11.9 \pm 1.4$ & 300 & 1000 \\
\hline $\mathrm{Cr}$ & $193.0 \pm 38.3$ & $69.9 \pm 13.0$ & 600 & 1000 \\
\hline $\mathrm{Zn}$ & $891.0 \pm 135.6$ & $341.3 \pm 69.2$ & 2000 & 3000 \\
\hline $\mathrm{Ni}$ & $109.0 \pm 22.3$ & $16.6 \pm 3.4$ & 100 & 200 \\
\hline
\end{tabular}

\section{Risk Assessment of Sludge Application}

Based on our results in Table II, all of the sewage sludge should not be directly used in agriculture, particularly due to the high total concentration of As in Shenyang sewage sludge and that of $\mathrm{Hg}$ in Ganqika sewage sludge. The high As concentration in sewage sludge may result from industrial source. The high Hg concentration in sewage sludge can be originated from sterilization in hospital and household. The possible final deposition according to German legislation law would be used for landfilling [7]. Otherwise, it could be chosen a method such as application to the forest land that could not enter into food chain.

\section{CONCLUSIONS}

Nowadays, it is necessary to find alternatives to recycling waste activated sludge in order to take environmental protection action. In this paper, we investigated properties of sewage sludge samples derived from municipal and small town domestic sewage treatment plant for assessing sludge application risk. Therefore, several tests were performed on the sludge samples, and data about their water and organic matter content, nutrient matter content, and heavy metal concentration were obtained. The contents of OM, N, P and $\mathrm{K}$ in sewage sludge are rich. However, the total concentrations of $\mathrm{As}, \mathrm{Hg}$ and $\mathrm{Ni}$ in two sewage sludge samples exceed regulatory limits at different degrees for sludge to be used in agriculture in China (GB18918-2002). Therefore, the sludge from those wastewater treatment plants should not be directly used in agriculture.

\section{ACKNOWLEDGMENT}

This work is funded by National Natural Science Foundation of China (41401262), National Key Technology Project of Water Pollution Controlling and Management of China (2012ZX07208-005, 2012ZX07505-003).

\section{REFERENCES}

[1] M. Surajit, R.D. Singh, A.K. Patra and B.S. Dwivedi, "Changes in soil quality in response to short-term application of municipal sewage sludge in a typic haplustept under cowpea-wheat cropping system," Environmental Nanotechnology, Monitoring \& Management, vol. 4, pp. 37-41, 2015.

[2] P. Mañas, E. Castro and J. de las Heras, "Application of treated wastewater and digested sewage sludge to obtain biomass from Cynara cardunculus L,” Journal of Cleaner Production, vol. 67, pp. 72-78, 2014.

[3] A. Franco, C.H. Abreu Junior, D. Perecin, F.C. Oliveira, A.C.R. Granja, and V.S. Braga, "Sewage sludge as nitrogen and phosphorus source for cane plant and first ratoon crops,” Revista Brasileira de Ciencia do Solo, vol. 34, pp. 553-561, 2010.

[4] T.A.R. Nogueira, A. Franco, Z.L. He, V.S. Braga, L.P. Firme and C.H. Abreu-Junior, "Short-term usage of sewage sludge as organic fertilizer to sugarcane in a tropical soil bears little threat of heavy metal contamination,” Journal of Environmental Management, vol. 114, pp. 168-177, 2013.

[5] R.P. Singh, and M. Agrawal, "Potential benefits and risks of land application of sewage sludge," Waste Management, vol. 28, pp. 347358, 2008.

[6] T. Bramryd, "Long-term effects of sewage sludge application on the heavy metal concentrations in acid pine (Pinus sylvestris L.) forests in a climatic gradient in Sweden,” Forest Ecology and Management, vol. 289, pp. 434-444, 2013.

[7] J.Y. Dai, M.Q. Xu, J.P. Chen, X.P. Yang and Z.S. Ke, "PCDD/F, $\mathrm{PAH}$ and heavy metals in the sewage sludge from six wastewater treatment plants in Beijing, China," Chemosphere, vol. 66, pp. 353361, 2007.

[8] A. Bianchini, L. Bonfiglioli, M. Pellegrini and C. Saccani, "Sewage sludge drying process integration with a waste-to-energy power plant,” Waste Management, vol. 42, pp. 159-165, 2015.

[9] J. M. Bremner, "Nitrogen-total," in Methods of soil analysis, Part 3. Chemical methods, D. L. Sparks, A. L. Page, P. A. Helmke, R. H. Loeppert, P. N. Soltanpour, M. A. Tabatabai, C. T. Johnston and M. E. Sumner, Eds. Wisconsin: Soil Science Society of America Book Series, Number 5, 1996, pp. 1085-1122. 